\title{
A systematic review on the utility of non-invasive electrophysiological assessment in evaluating for intra uterine growth restriction
}

Vinayak Smith ${ }^{1,2^{*}}$ (D, Amrish Nair ${ }^{2}$, Ritesh Warty ${ }^{2}$, Joel Arun Sursas ${ }^{2}$, Fabricio da Silva Costa ${ }^{1,3}$ and Euan Morrison Wallace ${ }^{1}$

\begin{abstract}
Background: Non-invasive electrophysiological assessment (NIEA) is an evolving area in fetal surveillance and is attracting increasing research interest. There is however, limited data outlining its utility in evaluating intra uterine growth restriction (IUGR). The objective of this study was to carry out a systematic review to outline the utility of NIEA parameters in evaluating IUGR.

Methods: A systematic review of peer reviewed literature was performed, searching PUBMED, Ovid MEDLINE and EMBASE. The outcomes of interest included NIEA parameters [P wave duration, PR interval, QRS duration, QT interval, T/ QRS ratio, short term variability (STV) and long term variability (LTV)] and a descriptive summary of relevant studies as well.

Results: Sixteen studies were identified as suitable for inclusion. The utility of NIEA parameters were investigated in tabular form. In particular, QRS and QT duration, T/QRS ratio, STV and PRSA analysis displayed utility and merit further consideration in evaluating for IUGR. Issues identified in the review were in relation to variances in definition of IUGR, small sample sizes and the lack of technological consistency across studies.
\end{abstract}

Conclusion: NIEA shows promise as an adjunct surveillance tool in fetal diagnostics for IUGR. Larger prospective studies should be directed towards establishing reliable parameters with a focus on uniformity of IUGR definition, technological consistency and the individualisation of NIEA parameters.

Keywords: Fetal electrocardiogram, Fetal magnetocardiogram, Cardiac time intervals, Short term variability, Long term variability , Intra uterine growth restriction, PRSA

\section{Background}

Approximately $11 \%$ of all pregnancies in developed nations and up to $23.8 \%$ of pregnancies in developing nations are complicated by intra uterine growth restriction (IUGR) $[1,2]$.

IUGR refers to the inability of a fetus to achieve its genetic growth potential in utero [3, 4]. Its aetiology may entail either maternal, fetal and placental factors, acting individually or in tandem, and is clinically differentiated

\footnotetext{
* Correspondence: Vinayak.smith@monash.edu

${ }^{1}$ Department of Obstetrics and Gynaecology, Monash University, 252 Clayton Road, Clayton, Victoria 3168, Australia

${ }^{2}$ Biorithm Pte Ltd, 81 Ayer Rajah Crescent 03-53, Singapore 139967,

Singapore

Full list of author information is available at the end of the article
}

into both early $(<32$ weeks of gestation) and late forms ( $\geq 32$ weeks) [5]. As a phenomenon, IUGR is a risk factor for both perinatal mortality and morbidity [6-8]. Emerging evidence further suggests that exposure to a hostile intra uterine environment can perpetuate through childhood too, with these fetuses being at risk of poor neurodevelopmental outcomes, long term physical growth, cardiovascular and endocrinological disease [9-11].

Clinically, fetal smallness is defined as the weight of fetus being below the 10th weight centile. There however remains some level of difficulty in differentiating isolated fetal smallness from IUGR, particularly at a late gestation, and in managing these findings as well $[4,12]$. Recognising this diagnostic dilemma, seminal work has 
been directed towards developing consensus criteria to accurately identify the IUGR fetus. There however, is still a lack of a gold standard which highlights an urgent need to characterise further tests [4].

In the current context, accurate identification also remains paramount as it would reduce the need for unnecessary interventions and monitoring, which have the benefits of a reduction in healthcare costs whilst negating the medicalisation of essentially normal pregnancies [3].

Non-invasive electrophysiological assessment (NIEA) is an evolving field in fetal diagnostics which is being mooted as a promising tool in fetal surveillance and discriminating between IUGR and normal fetuses. This involves the assessment of temporal and morphological characteristics from the electrophysiological activity of the fetal heart. At present, the technologies by which these can be done non-invasively include non-invasive fetal electrocardiography (NIFECG) and fetal magnetocardiography (FMCG) [13]. An in-depth discourse on these respective technologies can be found in Additional file 1 .

\section{Objectives}

Considering the aforementioned issues, the following systematic review was initiated following the PRISMA guidelines. The primary objective was to investigate and define the electrophysiological differences between IUGR and normal or appropriate for gestation age (AGA) fetuses utilising NIEA techniques (either NIFECG or MCG). We also aimed to correlate the utility of the identified NIEA methods with the existing literature in both animal and human models. Furthermore, we also intended to explore the potential physiological mechanisms through which the NIEA parameters enacted their discriminative ability.

\section{Materials and methods Data sources}

For the following review, a systematic search was undertaken independently by VS and JAS across PubMed, Ovid Medline and EMBASE up till 4th May 2018 and searched between 5th of May and 9th of May 2018. The search was subsequently repeated on the 24th of September 2018 and searched between the 25th of September and the 29th of September 2018 by both VS and JAS once again.

Search terms utilised for NIFECG were: "(fetal electrocardiogram AND iugr) OR (foetal electrocardiogram AND iugr) OR (fetal electrocardiogram AND intra uterine growth restriction) OR (foetal electrocardiogram AND intra uterine growth restriction) OR (fetal ecg AND iugr) OR (foetal ecg AND intra uterine growth restriction)".

Search terms utilised for FMCG were: (magnetocardiogra* AND iugr) OR (magnetocardiogr* AND intra uterine growth restriction) OR (mcg AND intra uterine growth restriction) OR (mcg AND iugr).
Taking technological factors into consideration, limitations were placed on studies that were published after 1980. There were no limitations placed on language. Both human and animal studies were considered for the following review.

The inclusion criteria for articles in this review were those focused on the utilisation of NIEA parameters in comparing the differences between IUGR and normal fetuses antenatally. Technology utilised for the acquisition of the cardiac time intervals (CTIs) were limited to only NIFECG and MCG. Articles were suitable for inclusion regardless of the aetiology of IUGR and clinical presentation (early or late forms). Preference was given to primary articles exploring these changes. Articles of relevance identified from the reference lists of studies searched were suitable for inclusion in the review as well. Articles which were reviews and comprised of case series or case reports were excluded from this review.

Once identified, articles for inclusion in the review were selected in consensus between JAS, VS and AN.

\section{Search strategy}

The search strategy for the following study is illustrated in Fig. 1 based on the updated search done on 25th of September 2018.

\section{Data collection process}

Data for the following study was extracted manually for analysis by VS and JAS. Due to the heterogeneity of the studied populations, variations in technologies, parameters utilised and end points of the studies, pooling of data for meta-analysis was not possible and not considered appropriate. As such, a narrative approach was followed for the following review and a descriptive and qualitative analysis of the studies was carried out to provide quality assessment.

\section{Data items}

Data items of interest for the following study were the study design, inclusion criteria for the study, method utilised to acquire signal, duration of signal sampling, signal processing method utilised, NIEA parameters utilised and results of those parameters in evaluating IUGR.

\section{Assessment of bias}

The risk of bias was assessed by VS and RW in consensus utilising the Modified Black and Downs list (Additional file 2). This is a tool which has been used widely to rate the quality of observational studies and is rated on a 10 point scale [14]. Fig. 2 illustrates the score of the studies included in the review. The scores were calculated as the average of scores between VS and RW and the questionnaire is included in the Appendix for reference. The interrater reliability between both raters was very high $(\mathrm{ICC}=0.949 ; p=$ 0.00 ) for the assessment of bias. 


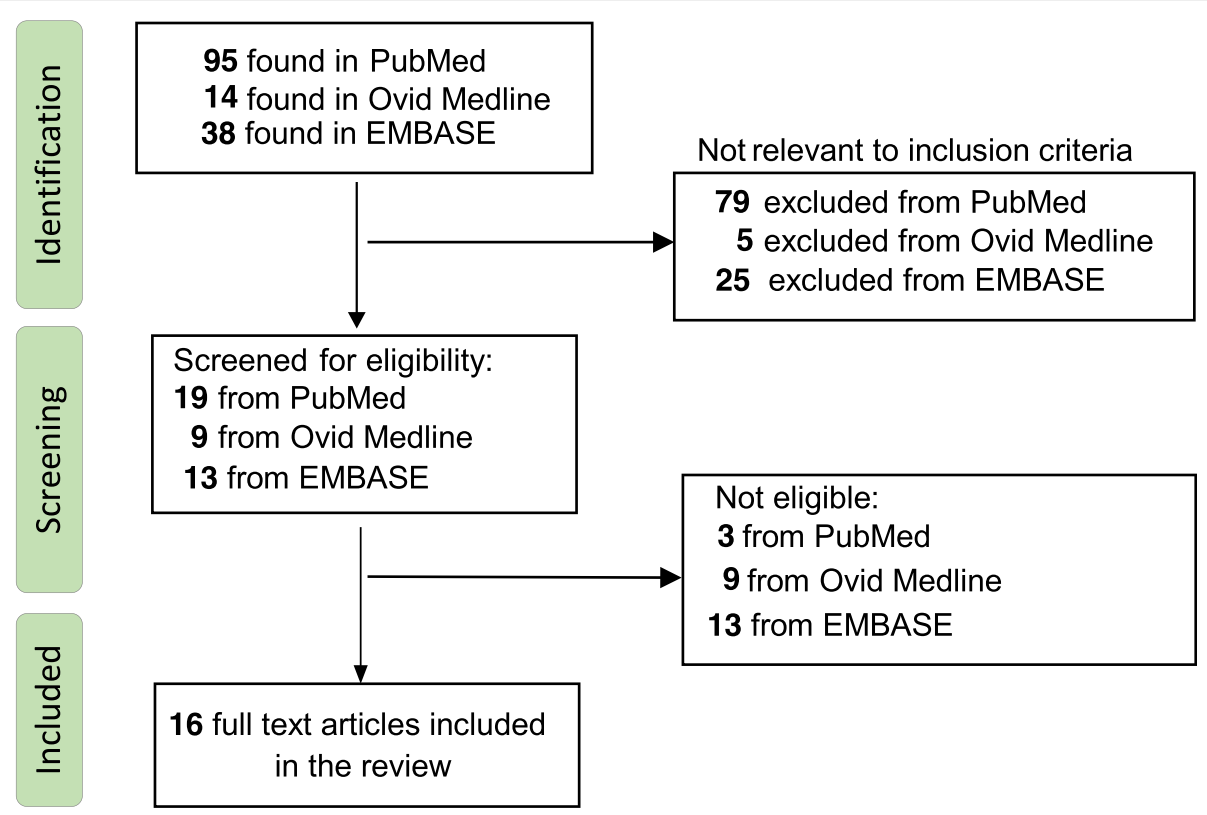

Fig. 1 Search strategy for the systemic review

\section{Summary measures and synthesis of results}

The summary measures for the following study were presented in tabular form for the following review. Importance was given to the NIEA parameters utilised in the studies as well as the signalling methods utilised to obtain them. We further sought to delineate the performance of the NIEA parameters in evaluating IUGR as well.

\section{Results}

\section{Characteristics of the studies}

For this review, a total of 16 studies were suitable for inclusion. Nine studies utilised NIFECG and 7 studies utilised magnetocardiography [15-30]. The characteristics of the studies and their findings have been illustrated in Tables 1 and 2 respectively. The studies were published between 1982 and 2017 and the gestational age of fetuses across studies ranged from 15 to 42 weeks across the studies.

\section{Qualitative analysis of studies}

The studies included in the review were analysed quantitatively for comparison. Tables 1 and 2 provide descriptive summaries of the studies and information in relation to their design for NIFECG and MCG respectively. Tables 3 and 4 provide a summary of the NIEA parameters utilised

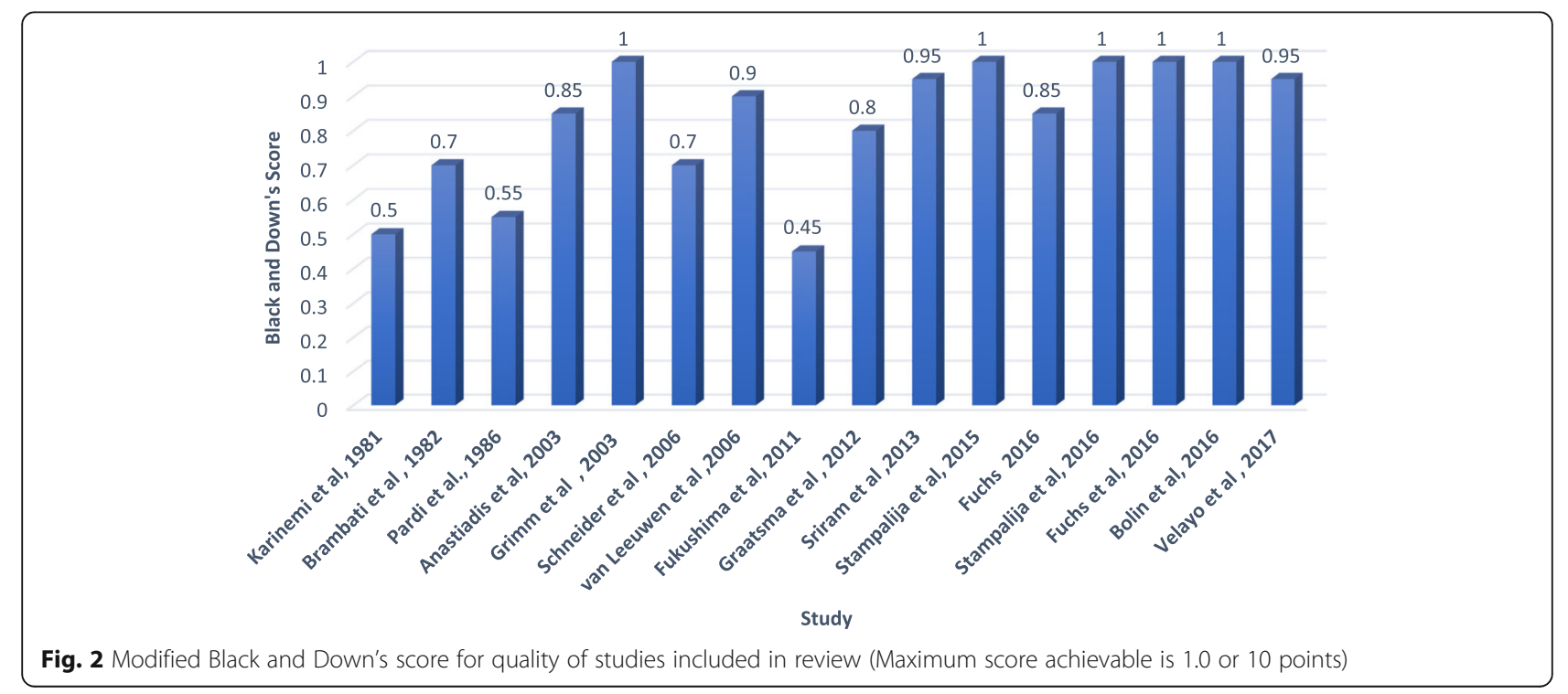


Table 1 : Descriptive summary of studies utilising non-invasive fetal electrocardiogram for NIEA analysis

\begin{tabular}{|c|c|c|c|c|c|c|c|}
\hline Year & Paper & $\begin{array}{l}\text { Study } \\
\text { population }\end{array}$ & Inclusion criteria & Definition of IUGR & $\begin{array}{l}\text { Acquisition } \\
\text { method }\end{array}$ & Signal acquisition & Signal processing \\
\hline 1981 & $\begin{array}{l}\text { Karinemi } \\
\text { et al. }\end{array}$ & $\begin{array}{l}\text { Case } \\
\text { control } \\
\text { study }\end{array}$ & $\begin{array}{l}N=65 \text { from normal } \\
\text { pregnancies with no } \\
\text { fetal acidosis at birth. } \\
n=68 \text { with IUGR. } n= \\
84 \text { with post dates } \\
\text { pregnancies }\end{array}$ & $\mathrm{BPD}<5 \%$ & $\begin{array}{l}\text { NIFECG using HP } \\
8030 \mathrm{~A} \\
\text { Cardiotocograph }\end{array}$ & $\begin{array}{l}\text { Recorded } \\
\text { manually on } \\
\text { magnetic tape } \\
\text { and digitalized at } \\
\text { a } 1000 \text { samples } \\
\text { per second) }\end{array}$ & $\begin{array}{l}\text { R-R intervals detected no } \\
\text { description provided) })^{\text {. }} \text { DI } \\
\text { sampled over } 5 \text { min. Upper } \\
\text { rejection limit of } 5 \text { bpm was } \\
\text { utilised }\end{array}$ \\
\hline 1982 & $\begin{array}{l}\text { Brambati } \\
\text { et al. }\end{array}$ & $\begin{array}{l}\text { Case } \\
\text { control } \\
\text { study }\end{array}$ & $\begin{array}{l}N=26 \text { of fetuses } \\
\text { suspected to be small } \\
\text { for dates }\end{array}$ & $\begin{array}{l}\text { Small for dates by } \\
\text { ultrasound or } \\
\text { clinical exam (no } \\
\text { explanation given) } \\
\text { BW }<10 \% \\
\text { postnatally. }\end{array}$ & $\begin{array}{l}\text { NIFECG- system } \\
\text { not specified }\end{array}$ & N/A & $\begin{array}{l}\text { MECG subtraction method } \\
\text { utilised. Signal delayed by } \\
180 \mathrm{~ms} \text { and } 50 \text { complexes } \\
\text { averaged }\end{array}$ \\
\hline 1986 & Pardi et al. & $\begin{array}{l}\text { Prospective } \\
\text { cohort } \\
\text { study }\end{array}$ & $\begin{array}{l}25 \text { to } 41 \text { weeks of } \\
\text { gestation. } n=68 \text {. } \\
\text { Fetuses with } \\
\text { malformations } \\
\text { excluded }\end{array}$ & $A C<5 \%$ & $\begin{array}{l}\text { NIFECG- system } \\
\text { not specified }\end{array}$ & N/A & $\begin{array}{l}\text { MECG subtraction method } \\
\text { utilised. Signal delayed by } \\
180 \mathrm{~ms} \text { and } 50 \text { complexes } \\
\text { averaged }\end{array}$ \\
\hline 2012 & $\begin{array}{l}\text { Graatsma } \\
\text { et al. }\end{array}$ & $\begin{array}{l}\text { Prospective } \\
\text { cohort } \\
\text { study }\end{array}$ & $\begin{array}{l}\text { 20-42 weeks of } \\
\text { gestation. Control }(n= \\
\text { 90),IUGR }(n=30)\end{array}$ & $\begin{array}{l}\text { EFW } \leq 10 \% \text { and } B W \\
\leq 10 \% \text { corrected for } \\
\text { GA }\end{array}$ & $\begin{array}{l}\text { NIFECG. Monica } \\
\text { AN24. } 5 \\
\text { electrodes } \\
\text { utilised }\end{array}$ & $\begin{array}{l}\text { Recorded with a } \\
\text { sample } \\
\text { frequency of } \\
1000 \mathrm{~Hz} \text {. } \\
\text { Duration }=7 \mathrm{~h}\end{array}$ & $\begin{array}{l}\text { In depth analysis available } \\
\text { from Pieri et al. }{ }^{b} \text { MECG } \\
\text { subtraction method utilised. } \\
50 \text { FECG complexes averaged }\end{array}$ \\
\hline 2015 & $\begin{array}{l}\text { Stampalija } \\
\text { et al. }\end{array}$ & $\begin{array}{l}\text { Case } \\
\text { control } \\
\text { study }\end{array}$ & $\begin{array}{l}\text { 26-34 weeks. IUGR } n= \\
\text { 22, Control } n=37 . \\
\text { Singleton pregnancies }\end{array}$ & $A C<5 \%$ & $\begin{array}{l}\text { NIFECG. Monica } \\
\text { healthcare. } 5 \\
\text { electrodes } \\
\text { utilised } \\
\text { transabdominally }\end{array}$ & $\begin{array}{l}40 \text { min } \\
\text { recording. } \\
\text { Sample } \\
\text { frequency of } \\
900 \mathrm{~Hz}\end{array}$ & $\begin{array}{l}\text { MECG subtraction method as } \\
\text { filter. FECG complexes } \\
\text { averaged over a } 2 \mathrm{~s} \text { window. } \\
\text { PRSA applied to entire trace } \\
\text { STV measured using Dawes } \\
\text { Redman criteria }\end{array}$ \\
\hline 2016 & $\begin{array}{l}\text { Stampalija } \\
\text { et al. }\end{array}$ & $\begin{array}{l}\text { Case } \\
\text { control } \\
\text { study }\end{array}$ & $\begin{array}{l}25-40 \text { weeks. IUGR }(n= \\
66) . \text { Control }(n=79) \\
\text { Singleton pregnancies }\end{array}$ & $A C<5 \%$ & $\begin{array}{l}\text { NIFECG. Monica } \\
\text { healthcare. } 5 \\
\text { electrodes } \\
\text { utilised } \\
\text { transabdominally }\end{array}$ & $37 \mathrm{~min}$. & $\begin{array}{l}\text { R-R wave pulse intervals were } \\
\text { calculated with an accuracy } \\
\text { of } 1 \text { ms. MECG subtraction } \\
\text { method as filter. FECG } \\
\text { complexes averaged over a } 2 \\
\text { S window. } \\
\text { PRSA applied to entire trace }\end{array}$ \\
\hline 2016 & $\begin{array}{l}\text { Fuchs et } \\
\text { al. }\end{array}$ & $\begin{array}{l}\text { Prospective } \\
\text { case control } \\
\text { study }\end{array}$ & $\begin{array}{l}\text { 28-42 weeks. IUGR }= \\
93, \text { IUGR with brain } \\
\text { sparing }=37 \text { and } 324 \\
\text { healthy pregnancies }\end{array}$ & $\begin{array}{l}\text { EFW }<5 \% \text { and only } \\
\text { asymmetrical IUGR } \\
\text { considered. BW was } \\
<10 \% \text { and ponderal } \\
\text { index }<10 \% \text { at birth }\end{array}$ & $\begin{array}{l}\text { NIFECG. } \\
\text { KOMPOREL } \\
\text { system. } 6 \\
\text { electrodes on } \\
\text { maternal } \\
\text { abdomen, }\end{array}$ & $\begin{array}{l}30 \text { min } \\
\text { recording. No } \\
\text { further } \\
\text { information } \\
\text { provided }\end{array}$ & No information provided \\
\hline 2016 & $\begin{array}{l}\text { Fuchs et } \\
\text { al. }\end{array}$ & $\begin{array}{l}\text { Prospective } \\
\text { case control } \\
\text { study }\end{array}$ & $\begin{array}{l}\text { 28-40 weeks. IUGR with } \\
\text { normal CPR }(n=110), \\
\text { IUGR with decreased } \\
\text { CPR }(n=29) \text { and } \\
\text { normal pregnancies } \\
(n=549)\end{array}$ & $\begin{array}{l}\text { EFW }<5 \% \text { and only } \\
\text { asymmetrical IUGR } \\
\text { considered. BW was } \\
<10 \% \text { and ponderal } \\
\text { index }<10 \% \text { at birth }\end{array}$ & $\begin{array}{l}\text { NIFECG. } \\
\text { KOMPOREL } \\
\text { system. } 6 \\
\text { electrodes on } \\
\text { maternal } \\
\text { abdomen, }\end{array}$ & $\begin{array}{l}30 \text { min } \\
\text { recording. No } \\
\text { further } \\
\text { information } \\
\text { provided }\end{array}$ & No information provided \\
\hline 2017 & $\begin{array}{l}\text { Velayo et } \\
\text { al. }\end{array}$ & $\begin{array}{l}\text { Human- } \\
\text { case control } \\
\text { study }\end{array}$ & $\begin{array}{l}\text { 20-34 weeks IUGR } n= \\
15, \text { Control } n=20 \text {. } \\
\text { Singleton pregnancies }\end{array}$ & EFW and $A C<10 \%$ & $\begin{array}{l}\text { NIFECG } 14 \\
\text { electrodes } \\
\text { transabdominally }\end{array}$ & $\begin{array}{l}20 \text { min } \\
\text { recordings } \\
\text { Bipolar } \\
\text { recording. } \\
\text { Sampling every } \\
1 \mathrm{~ms} \text { at } 1 \mathrm{kHz}\end{array}$ & $\begin{array}{l}\text { 1-100 Hz band pass filtering. } \\
\text { FECG signal averaging carried } \\
\text { out. }\end{array}$ \\
\hline
\end{tabular}


Table 2 : Descriptive summary of studies utilising Magnetocardiogram for NIEA analysis

\begin{tabular}{|c|c|c|c|c|c|c|c|}
\hline Year & Paper & $\begin{array}{l}\text { Study } \\
\text { population }\end{array}$ & $\begin{array}{l}\text { Gestational Age, } \\
\text { Inclusion \& Exclusion } \\
\text { criteria }\end{array}$ & $\begin{array}{l}\text { Definition } \\
\text { of IUGR }\end{array}$ & Acquisition method & $\begin{array}{l}\text { Signal } \\
\text { acquisition }\end{array}$ & Signal processing \\
\hline 2003 & Grimm et al. & $\begin{array}{l}\text { Case- } \\
\text { control } \\
\text { study }\end{array}$ & $\begin{array}{l}\text { 21-24 weeks. IUGR } n= \\
\text { 30. Control } n=60 \text {. }\end{array}$ & $\begin{array}{l}\text { EFW }<5 \% \\
\text { and } \\
\text { confirmed } \\
\text { BW } \\
\text { confirmed } \\
\text { IUGR }\end{array}$ & $\begin{array}{l}31 \text { channel SQUID } \\
\text { biomagnetometer }\end{array}$ & $\begin{array}{l}2 \text { min } \\
\text { recordings } \\
\text { sampling at } 1 \\
\mathrm{kHz} \text {. }\end{array}$ & $\begin{array}{l}\text { Band pass filters of } 0.3 \text { to } 500 \\
\text { Hz. Smoothing with Savitzky- } \\
\text { Goolay filter. Complex aver- } \\
\text { aging carried out and mater- } \\
\text { nal subtraction method } \\
\text { applied }^{\text {a }}\end{array}$ \\
\hline 2003 & $\begin{array}{l}\text { Anastasiadis } \\
\text { et al. }\end{array}$ & $\begin{array}{l}\text { Case } \\
\text { control } \\
\text { study }\end{array}$ & $\begin{array}{l}\text { 34-37 weeks. IUGR }(n= \\
\text { 11) Control }(n=19)\end{array}$ & $\begin{array}{l}\mathrm{AC}, \mathrm{HC} \text { or } \\
\mathrm{BPD}<2 \mathrm{SD} \\
\text { below the } \\
\text { average }\end{array}$ & $\begin{array}{l}\text { Single channel } \\
\text { biomagnetometer }\end{array}$ & $\begin{array}{l}32 \mathrm{~s} \text { duration } \\
\text { each. Sampling } \\
\text { frequency of } \\
256 \mathrm{~Hz} \text {. }\end{array}$ & $\begin{array}{l}\text { Power spectral analysis with } \\
\text { Fast Fournier transform. Band } \\
\text { pass filtered with cut off } \\
\text { frequency of } 0.1-100 \mathrm{~Hz}\end{array}$ \\
\hline 2006 & $\begin{array}{l}\text { Schneider et } \\
\text { al. }\end{array}$ & $\begin{array}{l}\text { Case } \\
\text { control } \\
\text { study }\end{array}$ & $\begin{array}{l}\text { 28-39 weeks. IUGR ( } n= \\
\text { 36) Control }(n=29) \\
\text { Exclusion criteria: known } \\
\text { cardiac or fetal } \\
\text { malformations, }\end{array}$ & $\begin{array}{l}\text { No } \\
\text { definition } \\
\text { of IUGR }\end{array}$ & $\begin{array}{l}31 \text { channel SQUID } \\
\text { biomagnetometer }\end{array}$ & $\begin{array}{l}5 \text { min } \\
\text { recording at a } \\
\text { sampling rate } \\
\text { of } 1000 \mathrm{~Hz}\end{array}$ & $\begin{array}{l}\text { Filtering band pass between } \\
0.3-500 \mathrm{~Hz} \text {. QRS complexes } \\
\text { averaged over } 256 \text { beats. }\end{array}$ \\
\hline 2006 & $\begin{array}{l}\text { Van } \\
\text { Leeuwen et } \\
\text { al. }\end{array}$ & $\begin{array}{l}\text { Case } \\
\text { control } \\
\text { study }\end{array}$ & $\begin{array}{l}\text { 15-42 weeks IUGR }(n= \\
\text { 27), Control }(n=47) \text {. } \\
\text { Singleton pregnancies. } \\
\text { Arrythmia and CHD } \\
\text { excluded }\end{array}$ & $\begin{array}{l}\text { EFW }< \\
10 \%\end{array}$ & $\begin{array}{l}230 \text { FMCG recorded from } \\
\text { normal foetuses. } 29 \text { FMCG } \\
\text { recorded from IUGR group, } \\
\text { Acquired using } 61 \text { or } 37 \\
\text { channel biomagnetometer }\end{array}$ & $\begin{array}{l}5 \text { min } \\
\text { recordings } \\
\text { Sampling at } 1 \\
\mathrm{kHz} \text {. }\end{array}$ & $\begin{array}{l}\text { Bandpass filters of } 1-200 \mathrm{kHz} \\
\text { Fetal beats identified on QRS } \\
\text { template using } 20-30 \text { beats. } \\
\text { PQRST averaged over } 300 \\
\text { beats for CTI. }\end{array}$ \\
\hline 2011 & $\begin{array}{l}\text { Fukushima } \\
\text { et al. (Power } \\
\text { spectral } \\
\text { analysis) }\end{array}$ & $\begin{array}{l}\text { Case } \\
\text { control } \\
\text { study }\end{array}$ & $\begin{array}{l}\text { 28-39 weeks. IUGR }(n= \\
\text { 12) and controls }(n= \\
\text { 35). }\end{array}$ & $\begin{array}{l}\text { EFW }< \\
10 \%\end{array}$ & $\begin{array}{l}64 \text { channel SQUID } \\
\text { biomagnetometer }\end{array}$ & $\begin{array}{l}5 \text { min } \\
\text { recordings. }\end{array}$ & $\begin{array}{l}\text { Maternal subtraction method } \\
\text { utilised. Means were average } \\
\text { over } 300-500 \text { beats. Power } \\
\text { spectrum in frequency } \\
\text { domain derived from } \\
\text { maximum entropy method. } \\
\text { LF domain } 0.01-0.15 \mathrm{~Hz} \text {. HF } \\
\text { domain } 0.15-0.4 \mathrm{~Hz}\end{array}$ \\
\hline 2013 & Sriram et al. & $\begin{array}{l}\text { Case } \\
\text { control } \\
\text { study }\end{array}$ & $\begin{array}{l}\text { 30-38 weeks. IUGR. Only } \\
\text { heart rate data for sleep } \\
\text { states were analysed }\end{array}$ & $\begin{array}{l}\text { EFW }< \\
10 \%\end{array}$ & $\begin{array}{l}151 \text { sensor SQUID array } \\
\text { system. } N=40 \text { available for } \\
\text { analysis. Pattern A was } \\
\text { quiet sleep state and } \\
\text { pattern B was active sleep } \\
\text { state. }\end{array}$ & $\begin{array}{l}\text { Between } 10 \\
\text { and } 30 \text { min. } \\
\text { Sampling rate } \\
\text { of } 312.5 \mathrm{~Hz}\end{array}$ & $\begin{array}{l}\text { Band pass filtered between } \\
0.5 \text { to } 50 \mathrm{~Hz} \text {.Hibert transform } \\
\text { approach utilised to identify } \mathrm{R} \\
\text { waves. Parameters derived } \\
\text { from } 6 \text { min windows }\end{array}$ \\
\hline 2016 & Bolin et al. & $\begin{array}{l}\text { Case } \\
\text { control } \\
\text { study }\end{array}$ & $\begin{array}{l}\text { 33-37 weeks. IUGR ( } n= \\
\text { 21), hypertensive } \\
\text { mothers }(n=46) \text { and } \\
\text { control }(n=74) \text {. No fetal } \\
\text { cardiac pathology or } \\
\text { arrythmias. }\end{array}$ & $\begin{array}{l}\text { EFW }< \\
10 \%\end{array}$ & $\begin{array}{l}151 \text { sensor SQUID array } \\
\text { system. }\end{array}$ & $\begin{array}{l}\text { CTI averaged } \\
\text { over } 1 \text { min } \\
\text { after maternal } \\
\text { with maternal } \\
\text { subtraction } \\
\text { method }\end{array}$ & Not described \\
\hline
\end{tabular}

$A C$ abdominal circumference, $B P D$ bi parietal diameter, CTI cardiac time intervals, EFW estimated fetal weight, $H C$ head circumference, IUGR intra uterine growth restriction, $S D$ standard deviation. ${ }^{\text {a. }}$ Schneider $U$ et al. [67]

specifically in each of these studies and a summary of their findings as well.

\section{Variation in definition of IUGR}

There was a variety of definitions utilised for IUGR as inclusion criteria across the studies included in the review. Some adopted an ultrasonographic measure of estimated fetal weight below the 5th centile while others utilised a measure below the 10th centile. Other studies utilised isolated ultrasound parameters such as the Biparietal diameter, head circumference or abdominal circumference as part of their inclusion criteria. Finally, two studies utilised post-delivery birth weights and the ponderal index as inclusion criteria for their study. The various definitions can be sourced in Tables 1 and 2 respectively.

\section{NIEA parameters}

The findings of the review in terms of the NIEA parameters and their utility in evaluating IUGR are presented in tabular form in Tables 3 and 4.

\section{A. $P$ wave duration}

Utilising MCG, Bolin et al. demonstrated a significantly shorter $\mathrm{P}$ wave duration in the IUGR group in comparison to the AGA group (66.4 vs $76.2 \mathrm{~ms} ; p=0.001,29$ ]. These findings however, were isolated and not mirrored by any other studies in this review. Van Leeuwen et al. noted that the $\mathrm{P}$ wave duration was non-significantly 
Table 3 Findings of NIEA parameters in studies utilising non-invasive fetal electrocardiogram

\begin{tabular}{|c|c|c|c|}
\hline$\overline{\text { Year }}$ & Paper & Parameters assessed & Findings \\
\hline 1981 & $\begin{array}{l}\text { Karinemi } \\
\text { et al. }\end{array}$ & STV using DI & $\begin{array}{l}95.4 \% \text { of NIFECG were successfully acquired. The distribution of DI in the IUGR } \\
\text { group was significantly different to the normal cohort }(p<0.001) \text {. DI had sensitivity } \\
\text { of } 64 \% \text { and predictive value of } 80 \% \text { in screening for fetal distress in the IUGR } \\
\text { group }(p<0.01)\end{array}$ \\
\hline 1982 & $\begin{array}{l}\text { Brambati } \\
\text { et al. }\end{array}$ & QRS & $\begin{array}{l}100 \% \text { of NIFECG were successfully analysed } 96.2 \% \text { of SFD fetuses had QRS duration } \\
\text { less then } 2 \text { SD below the normal values for gestation. QRS duration (in pregnancy) } \\
\text { and live birthweight demonstrated a strong relation ( } r=0.74, p<0.001)\end{array}$ \\
\hline 1986 & Pardi et al. & QRS & $\begin{array}{l}100 \% \text { of NIFECG were successfully analysed. } 81.5 \% \text { of IUGR fetuses had QRS } \\
\text { duration less then } 2 \text { SD below the normal values for gestation. QRS duration (in } \\
\text { pregnancy) and live birthweight demonstrated a linear relation }(r=0.69, p<0.001) \\
\text { QRS values }>4 \text { SD below normal were related with abnormal CTG, low APGAR and } \\
\text { perinatal deaths }\end{array}$ \\
\hline 2012 & $\begin{array}{l}\text { Graatsma } \\
\text { et al. }\end{array}$ & FHR PRSA- AC/DC STV & $\begin{array}{l}\text { STV increased in early gestation with stable 3rd trimester values AC and DC } \\
\text { remained constant during pregnancy irrespective of gestation. STV abnormal in 16\% } \\
\text { of the IUGR fetuses AC and DC abnormal in } 36 \text { and } 40 \% \text { of IUGR Z scores for IUGR } \\
\text { fetuses for STV, AC and DC were lower by } 1.0 S D, 1.5 S D \text { and } 1.75 D \text { respectively in } \\
\text { comparison to the controls [mean of z- Scores, 0;SD-1, }(p<0.0001) \text { ] In IUGR group, } \\
\text { AC and DC z scores were lower than STV scores. When STV z score was utilised with } \\
\text { AC and/or DC Z-scores, the findings of deviation became more accentuated }\end{array}$ \\
\hline 2015 & $\begin{array}{l}\text { Stampalija } \\
\text { et al. }\end{array}$ & PRSA STV & $\begin{array}{l}\text { Significantly lower } A C \text { and } D C \text { in IUGR vs controls }(p<0.05) \text { for any } T \geq 5 \text { values } \\
\text { AUC for AC }[0.63(95 \% \mathrm{Cl} 0.47-0.78)-0.87(95 \% \mathrm{Cl} 0.77-0.96)] \text { and } \mathrm{DC}[0.64(95 \% \mathrm{Cl} \\
0.48-0.79)-0.89(95 \% \mathrm{Cl} 0.81-0.98)] \text { STV significantly lower between IUGR and } \\
\text { controls }(8.6 \pm 2.4 \mathrm{vs} 11.1 \pm 2.6 \mathrm{~ms} \text {. P }=0.001) \text {. AUC for STV } 0.77(95 \% \mathrm{Cl} 0.65-0.90) \\
\text { AUC for PRSA significantly outperformed STV }\end{array}$ \\
\hline 2016 & $\begin{array}{l}\text { Stampalija } \\
\text { et al. }\end{array}$ & PRSA- AC/DC at T9 & $\begin{array}{l}\text { AC and DC at T9 were significantly lower in IUGR vs controls after adjusting for GA } \\
{[\mathrm{OR}=2.1,95 \% \mathrm{Cl} 1.5-3.0 \text { and } \mathrm{OR}=0.595 \% \mathrm{Cl} 0.36-0.68, p<0.001) \mathrm{AC} \text { and } \mathrm{DC} \text { at T9 }} \\
\text { were higher for IUGR with brain sparing vs those without brain sparing }(\mathrm{OR}=1.8 \text {, } \\
95 \% \mathrm{Cl} 0.97-3.4, p=0.06 \text { and } \mathrm{OR}=0.595 \% \mathrm{Cl} 0.30-0.98, p=0.04)\end{array}$ \\
\hline 2016 & $\begin{array}{l}\text { Fuchs et } \\
\text { al. }\end{array}$ & $\begin{array}{l}\text { T/QRS ratio STV FIGO classification of CTG- } \\
\text { normal, suspicious and pathological }\end{array}$ & $\begin{array}{l}\text { STV in normal pregnancies }(9.08 \pm 3.91) \text { were significantly different }(p<0.05) \text { from } \\
\text { IUGR with brain sparing }(11.33 \pm 1.38) \text { and IUGR without brain sparing }(10.16 \pm 4.98) \\
\text { T/QRS values were all below the cut off for abnormal results across all groups } \\
\text { Highest average T/QRS ratio }(>0.3) \text { seen in IUGR with brain sparing regardless of } \\
\text { FIGO classification of CTG No correlation found between T/QRS ratio and FIGO } \\
\text { classification of CTG }\end{array}$ \\
\hline 2016 & $\begin{array}{l}\text { Fuchs et } \\
\text { al. }\end{array}$ & T/QRS ratio & $\begin{array}{l}\text { Regression did not show any significant differences between groups in relation to } \\
\text { GA and T/QRS ratio. T/QRS ratios demonstrated significant differences between } \\
\text { IUGR group with reduced CPR and normal CPR }(p<0.001) \text { When using the } \\
\text { maximum values and maximum - minimum values, the regression line descends in } \\
\text { group with normal CPRs but rises in group with reduced CPR. }\end{array}$ \\
\hline 2017 & $\begin{array}{l}\text { Velayo et } \\
\text { al. }\end{array}$ & $\begin{array}{l}\mathrm{QT}, \mathrm{RR}, \mathrm{QRS}, \mathrm{ST}, \mathrm{PR} \text { and } \mathrm{PQ} \text { intervals. QTc, } \\
\mathrm{PR} / \mathrm{RR} \text { and } \mathrm{HR}\end{array}$ & $\begin{array}{l}\text { 100\% of PQRST were recognised. Both QT and QTc parameters were significantly } \\
\text { prolonged }(p<0.05) \text {. QT }>267.99 \text { has a sensitivity of } 80.0 \% \text { and a PPV of } 40 \% \text { for } \\
\text { IUGR. QTc }>0.43 \text { had a sensitivity }>86.7 \% \text { and PPV of } 40.6 \% \text {. }\end{array}$ \\
\hline
\end{tabular}

$A C$ acceleration component, CTG cardiotocogram, CPR cerebroplacental ratio, DC deceleration component, DI differential index, IUGR intra uterine growth restriction, NIFECG non-invasive fetal electrocardiogram, PRSA phase rectified signal averaging, SD standard deviation, SFD small for dates, STV short term variability

shorter in the IUGR fetuses in comparison to the AGA fetuses. They also noted that these changes were more apparent in female in comparison to male fetuses [26]. Grimm et al. did not demonstrate any discriminative ability of the P wave duration in differentiating the IUGR fetuses from AGA fetuses. They also reported a significantly prolonged PR interval in their AGA which was not evident in their IUGR group [20]. Utilising NIFECG, Velayo et al. demonstrated no discriminative ability for the $P$ wave duration in differentiating IUGR from AGA [27].

In summary, the $\mathrm{P}$ wave duration did not prove useful in differentiating between IUGR and AGA fetuses.

\section{B. PR interval}

Bolin et al. found PR intervals in the IUGR fetuses to be significantly shorter than that of AGA fetuses. Again, these findings were isolated and not mirrored by any other studies [29]. Van Leeuwen et al., utilising MCG, noted that the PR interval was non-significantly shorter in the IUGR fetuses in comparison to the AGA fetuses. It however, did not discriminate between the groups. Similarly, Grimm et al. did not identify any discriminative ability for the PR interval. Utilising NIFECG, Velayo et al. demonstrated no discriminative ability for the PR interval in differentiating IUGR from AGA [27]. 
Table 4 Findings of NIEA parameters in studies utilising magnetocardiography

\begin{tabular}{|c|c|c|c|}
\hline Year & Paper & Parameters assessed & Findings \\
\hline 2003 & Grimm et al. & $\begin{array}{l}\text { P wave, PR interval, QRS complex and QT } \\
\text { interval }\end{array}$ & $\begin{array}{l}\text { P and QRS detected in } 100 \% \text {. T waves detected in } 95 \% \text { of fetuses. P wave and } \\
\text { QRS complex length demonstrated significant correlation with GA in AGA } \\
\text { fetuses }(r=0.222 / 0.318, p<0.05 \text { ). No correlation was seen in IUGR group. QRS } \\
\text { duration was longer in IUGR group vs control group }(p=0.009)\end{array}$ \\
\hline 2003 & $\begin{array}{l}\text { Anastasiadis } \\
\text { et al. }\end{array}$ & HRV measured through: LF and HF & $\begin{array}{l}\text { LF and HF components were significantly lower in IUGR group }(p<0.001) \text {. } \\
\text { Increased LF tone in IUGR fetuses indication of increased sympathetic tone. HF } \\
\text { tone was increased in IUGR as well }\end{array}$ \\
\hline 2006 & $\begin{array}{l}\text { Schneider et } \\
\text { al. }\end{array}$ & $\begin{array}{l}\text { HRV measured through: SDNN, RMSSD, LF, HF, } \\
\text { LF/HF ratio, TP, complexity of AIF decay }\end{array}$ & $\begin{array}{l}\text { SDNN, RMSSD, LF,HF and TP were significantly lower in IUGR group }(p<0.05) \\
\text { No significant difference in LF/HF ratio and AIF decay. }\end{array}$ \\
\hline 2006 & $\begin{array}{l}\text { Van } \\
\text { Leeuwen et } \\
\text { al. }\end{array}$ & $\begin{array}{l}\mathrm{P} \text { wave, } \mathrm{PQ} \text { segment, } \mathrm{QRS} \text { complex, } \mathrm{ST} \\
\text { segment, T wave, } \mathrm{PR} \text { interval and Qt interval }\end{array}$ & $\begin{array}{l}100 \% \text { of CTIs acquired. IUGR foetuses had shorter depolarization times (P wave, } \\
\text { PR interval, QRS complex) and longer ventricular repolarization times (QT } \\
\text { interval) then controls. Depolarization times had a positive correlation with fetal } \\
\text { weight in the IUGR group [Pwave ( } r=0.64) \text {, QRS ( } r=0.47), p<0.05 \text { ] }\end{array}$ \\
\hline 2011 & $\begin{array}{l}\text { Fukushima } \\
\text { et al. }\end{array}$ & HRV measured through PSA: CV RR, LF/HF ratio & $\begin{array}{l}\mathrm{CV}_{\text {RR }} \text { in controls showed a weak positive correlation with GA }(r=0.32) \text { while } \\
\text { IUGR fetuses showed no such trend }(r=0.05) \text {. LF/HF ratio showed a moderate } \\
\text { positive correlation with GA for controls }(r=0.49) \text { but a weak correlation with } \\
\text { IUGR ( } r=0.23) \text { No statistically significant changes in LF/HF ratio between } \\
\text { normal pregnancy and IUGR groups }\end{array}$ \\
\hline 2013 & Sriram et al. & HRV measured through: PPA,SDNN,RMSSD & $\begin{array}{l}\text { IUGR group had lower HRV vs low risk group Using PPA - Both HRV in state A } \\
\text { and B were lower ( } 36 \text { and } 49 \% \text { lower, } p<0.005 \text { ) Using SDNN- Both HRV in State } \\
A \text { and B were lower ( } 19 \text { and } 49 \%, p<0.005) \text { RMSSD -not statistically significant }\end{array}$ \\
\hline 2016 & Bolin et al. & $\begin{array}{l}\text { P wave, PR interval, QRS complex and RR } \\
\text { interval }\end{array}$ & $\begin{array}{l}\text { Mean } P \text { and PR interval were significantly lower in IUGR group then normal } \\
\text { pregnancies }(p<0.05) \text { when normalised to } 35 \text { weeks of gestation }\end{array}$ \\
\hline
\end{tabular}

$A G A$ appropriate for gestational age, $A I F$ autonomic information flow, $C V_{R R}$ coefficient of R-R variability, GA gestational age, IUGR intra uterine growth restriction, $H F$ high frequency, HRV heart rate variability, LF low frequency, PPA phase plane area, RMSSD root mean square difference of successive heart rates, SDNN standard deviation of heart rate, TP total power

In summary, the PR interval did not prove useful in differentiating between IUGR and AGA fetuses.

\section{QRS duration}

The following studies demonstrated significantly shortened QRS durations in fetuses with IUGR in comparison to AGA fetuses [16, 20, 22, 26]. Both Brambati et al. and Pardi et al. demonstrated that 96.2 and $81.5 \%$ of IUGR fetuses respectively had a QRS duration less then 2SD below the normal values for gestation. Van Leeuwen et al. mirrored these findings male fetuses only in their MCG study [26]. Grimm et al. in contrast paradoxically demonstrated a significantly longer QRS duration in the IUGR group in comparison to the AGA [20]. Velayo et al. and Bolin et al demonstrated no discriminative ability for the QRS duration in differentiating IUGR from AGA [27, 29].

In summary, the utility of the QRS duration remains equivocal in differentiating IUGR from AGA fetuses.

\section{QT interval}

Utilising NIFECG, Velayo et al. showed significant discriminative ability for the QT interval in distinguishing between IUGR and AGA fetuses. Utilising a QT value of $\leq 267.99$ provided a sensitivity of $80.0 \%$ and specificity of $10 \%$ with a positive predictive value (PPV) of $40.0 \%$ [27].
Van Leeuwen et al. and Grimm et al. did not demonstrate any discriminative ability for the QT interval utilising MCG [20, 26].

As such, the utility of the QT interval remains equivocal in differentiating IUGR fetuses.

\section{E. T/QRS ratio}

Fuchs et al. utilising NIFECG demonstrated the utility of the T/QRS ratio in evaluating IUGR. Utilising multivariate regression analysis, they demonstrated the utility of maximum, and difference between maximum and minimum T/QRS values in differentiating between IUGR fetuses with normal and abnormal cerebroplacental ratios [17]. They were however unable to replicate these results in their subsequent study as the maximum and mean T/ QRS values were all below the cut-off level for abnormal levels $[17,18]$.

As such, the T/QRS ratio remains equivocal in differentiating IUGR fetuses.

\section{F. Short term variability (STV)}

All studies utilising NIFECG to examine the efficacy of STV, demonstrated its discriminative capacity between IUGR fetuses and AGA fetuses. Stampalija et al. demonstrated lower STV levels in IUGR fetuses in comparison to AGA fetuses [25]. Similar findings were mirrored by Graatsma et al. when utilising $\mathrm{z}$ scores for comparison and by Karinemi et al. when utilising the differential 
index with a cut-off level below the 1st centile of normal derived from controls in their study [19]. The STV values determined by Fuchs et al. however, were all above the commonly used cut-offs for pathological levels. In addition, they paradoxically demonstrated that the STV values were higher in IUGR fetuses [18] .

As such, the utility of STV appears promising for differentiating IUGR from AGA fetuses.

\section{G. Long term variability (LTV)}

In assessing the LTV, a variety of signal processing methods were utilised. These include:

\section{H. Phase rectified signal averaging (PRSA) - AC/DC analysis} All studies utilising PRSA analysis demonstrated significant differences between IUGR and AGA fetuses when utilising NIFECG. Graatsma et al. demonstrated lower $\mathrm{AC} / \mathrm{DC} \mathrm{z}$ scores in the IUGR fetuses in comparison to the controls. Importantly, they found that the screening potential of low AC/DC values was more accentuated when combining $<-1$ SD z scores of STV to the algorithm [19]. Stampalija et al. in both their studies demonstrated the significantly lower AC/DC values in their IUGR groups. Of note is the finding of PRSA analysis significantly outperforming STV in their study when utilising receiver operator characteristic (ROC) curves [24, 25].

As such, the utility of PRSA appears promising in differentiating IUGR from AGA fetuses.

\section{Other techniques}

Anastasiadis et al., Sriram et al., Fukushima et al and Schneider et al all utilised a variety of signal processing techniques to measure LTV utilising MCG. Anastasiadis et al. and Schneider et al. demonstrated significantly lower low and high frequency components in analysis of LTV for IUGR fetuses in comparison to the controls using power spectral analysis $[15,28]$. Both Schneider et al. and Fukushima et al. however could not ascribe any discriminative ability to the utilisation of the LF/HF ratio. Sriram et al. and Schneider et al utilised several methods to measure LTV including traditional heart rate variability measurements such as SDNN and Root Mean Square of Successive Differences (RMSSD), as well as non-linear methods, such as phase plane analysis (PPA). Both studies noted that the Standard Deviation of Normal to Normal (SDNN) was significantly lower in the IUGR fetuses in comparison to the AGA ones. The results for the (RMSSD) however were conflicting between both studies. Amidst these findings, the discriminative ability of phase plane area (PPA) analysis in particular bears mention as it was able to capture the LTV changes in both quiet and active states of the fetus [23, 28].

Given the findings, the LTV analysis techniques appear promising in evaluating IUGR.

\section{Discussion}

\section{NIEA parameters}

For the following discussion, attempts were made to correlate the findings of our review with the existing literature in both animal and human models. The focus was to draw parallels with the findings from other studies utilising either the CTG, NIFECG or invasive electrocardiography to examine the differences between IUGR and AGA fetuses for the NIEA parameter of interest .

\section{Cardiac time intervals (CTIs)}

CTI analysis utilises a variety of automated computational methods to extract the PQRST waveforms from both the NIFECG and MCG for analysis. Broadly speaking, these encompass signal detection, enhancement, waveform detection and techniques for signal enhancement. These techniques however are beyond the scope of the review but can be accessed from previous work by our group [31].

Morphologically, the FECG and MCG are similar to the adult ECG and contain the P wave, QRS complex and $\mathrm{T}$ wave as illustrated in Fig. 3. The temporal intervals of significance include the $\mathrm{P}$ wave duration, $\mathrm{PR}$ interval, QRS duration, QT interval and T/QRS ratio. Information regarding these parameters can be sourced from previous work by our group [31] .

\section{A. $P$ wave and $P R$ interval}

There is no evidence in the literature to which has demonstrated significant differences between the $\mathrm{P}$ wave and PR interval between IUGR and AGA fetuses which is in line with the findings of this review.

\section{B. QRS duration}

In examining the literature, the study by Brambati et al. utilising NIFECG deserves consideration. In their study on pregnancies afflicted by rhesus immunization, fetuses with cardiac hypertrophy and compensation displayed a QRS duration more than 4SD above the normal mean value. This allowed for improved detection of decompensating fetuses and those at risk of a worse prognosis [32].

The equivocal findings of this review for the QRS duration may be related to its weakly discriminative ability to screen for ventricular hypertrophy which is seen in a subset of IUGR fetuses with cardiac remodelling. As such, the QRS duration may have a yet uncovered role in distinguishing between IUGR and AGA fetuses.

\section{QT interval}

There is, however, no evidence in the literature describing differences in the QT interval between IUGR and AGA fetuses.

Interestingly, Velayo et al., utilising NIFECG, demonstrated shortening of the QT interval in the recipient 


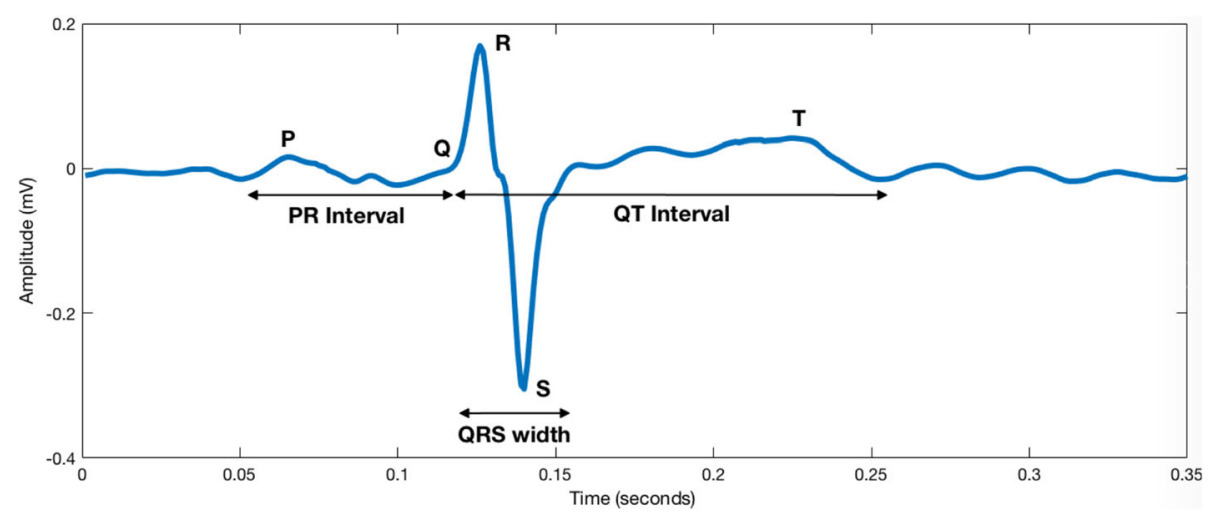

Fig. 3 Cardiac time intervals illustrated on a fetal ECG beat. The following beat was extracted from the Physionet database. This was aresult of 10 averaged beats after the maternal ECG was cancelled.

fetus in twin -to- twin- transfusion syndrome (TTTS). Given the diastolic dysfunction that these fetuses experience, one may hypothesize that this may signify deteriorating ventricular performance in the fetus [33].

In the context of the equivocal findings for the QT interval in this review, its utility in IUGR evaluation is worth exploring as well.

\section{T/QRS ratio}

The T/QRS ratio is calculated by comparing the amplitude of the $\mathrm{T}$ wave with the amplitude of the QRS complex. This ratio was proposed as a quantitative measure of the $\mathrm{T}$ wave amplitude to eliminate issues with signal gain and amplification from transabdominal electrodes. The T/QRS ratio is known to be affected by myocardial hypoxia and may serve as a marker for it [34-37].

Widmark et al. in their study with guinea pigs utilising the fetal scalp electrode (FSE) utilised the T/ QRS ratio to differentiate between growth restricted guinea pigs and controls. They too however, found no utility for the T/QRS ratio in differentiating between both groups [36].

It must be mentioned however, that the T/QRS ratio is not one which is normally distributed and may require individualisation for clinical application. This could possibly explain inconsistencies in the marker when cut-offs were utilised for detection of fetal hypoxia. Van Wijngaarden et al. instead proposed individualised cut-offs to be calculated per patient and found discriminative ability for hypoxia when there was an increase over the 97.5th and 99.5th centile for 2 consecutive minutes [38].

In the context of these findings, there may yet be a potentially unproven role for $\mathrm{T} / \mathrm{QRS}$ ratios in distinguishing between IUGR and AGA fetuses. These values, however, may need to be individualised to the fetus and carried out temporally in order to be of value.

\section{E. Heart rate variability (HRV) STV}

The STV is a computerised approximation of a physiological process which interrogates the interplay between the sympathetic, parasympathetic and peripheral chemoreceptors [39]. It measures the beat to beat variation of the fetal heart which cannot be discerned from visual inspection of the CTG alone [39, 40].

In evaluating the discriminating role of STV, several animal studies remain informative. Widmark et al., utilising a guinea pig model, noted STV to be lower in IUGR fetuses in comparison to their AGA counterparts while using invasive electrocardiography $(1.96 \pm 0.18$ vs $3.41 \pm 0.32$; $p<$ 0.02). Similarly, in a study by Morutsuki et al. utilising chest electrodes and the Dawes Redman criteria, sheep fetuses with IUGR had a $20 \%$ significantly reduced STV in comparison to AGA fetuses $(8.8 \pm 0.5$ vs $10.6 \pm 0.5 \mathrm{~ms} ; p<$ 0.05). Likewise, utilising invasive electrocardiography, Minato et al. demonstrated STV to be significantly lower in mice with IUGR in comparison to their AGA counterparts (3.31 vs $7.58 \mathrm{~ms} ; p=0.0045$ ) [41].

The available data on STV therefore does seem to suggest that it is consistently lower in IUGR fetuses in comparison to controls of similar gestations and that it may have a yet unfounded role in differentiating between both groups.

\section{F. Long term variability \\ 1. Classical methods}

The long-term variability (LTV) is a commonly used marker on the CTG to assess the interplay between the sympathetic and parasympathetic trunks of the autonomic nervous system of the fetus. It is commonly assessed by clinicians using visual inspection and as such is subject to observer and measurement bias [42, 43]. Classically, methods which have been utilised to quantify this interplay of the fetal cardiac system include the RMSSD and SDNN. 
In a recent study utilising computerised cCTG (cCTG), Stroux et al. examined the differences between IUGR fetuses from AGA controls using LTV in various parts of their sleep and wake cycles. Their data showed a lower percentage of high variability (active sleep) episodes in fetuses with IUGR compared to controls. In particular, these findings were more pronounced in the gestations $\leq 34$ weeks, where reduced LTV during active sleep states showed an AUC of 74\% (70-78\%) for distinguishing fetuses with IUGR from AGA fetuses [44].

Another method which is utilised to interrogate this interplay is power spectral analysis (PSA). PSA attempts to quantify the chaotic and dynamic interplay of heart rate variability and attempts to functionally measure the elasticity of the cardiac regulating system as well as the sympthovagal balance. $[45,46]$. The low frequency (LF) components are generally thought to correlate with sympathetic tone while the high frequency (HF) components are postulated to correlate with parasympathetic tone and respiratory sinus arrythmia $[15,47]$.

IUGR fetuses are theorised to have a decreased level of correlation between the HF and LF due to their chronically hypoxic state which in turn negates their ability to compensate to in utero stressors [15]. The study by Anastasiadis et al. remains informative in this context.

In line with the findings of the review, the discriminative ability of the HF and LF components also resonate with the study conducted by Ohta et al which demonstrated a correlation in IUGR fetuses with LF components and fetal oxygen and $\mathrm{pH}$ levels post delivery [47].

\section{Novel methods}

In recent times however, increasing attention is being directed to non-linear methods to quantify and provide a more physiological measure of the interplay between the parasympathetic and sympathetic trunks of the nervous system and modulation on cardiac functionality [48]. The techniques utilised by studies in this review include:

\section{Phase rectified signal averaging (PRSA)}

PRSA is an algorithm utilised in signal processing to identify quasi-periodic patterns in a signal which can be masked by the non-stationary nature of the associated signal and noise [49]. It is increasingly being mooted as an alternative measure of STV [50]. This method of signal processing may be better suited to the NIEA signals given its quasi stationary nature. The algorithm measures both the acceleration capacity (AC) and deceleration capacity (DC) of the fetal heart and aims to explore the individualised effects of both arms of the autonomic nervous system (ANS) [51].

Three studies in this review utilised PRSA in evaluating IUGR $[19,24,25]$.
The study by Lobmaier et al. examined the differences between IUGR fetuses (with and without doppler changes) and AGA fetuses utilising the AC component on cCTG against STV. They noted AAC to have outperformed STV for detection of IUGR. AAC had a PPV and NPV of $90 \%$ while STV had a PPV of $71 \%$ and NPV of $81 \%$. Furthermore, the area under the curve (AUC) for AC was 97\% [95\% CI 0.95-1.0] whilst that for STV was 0.85 (95\% CI 0.76-0.93). The optimum cut-off level for AC was determined to be $2.4 \mathrm{bpm}$ [52].

As such, PRSA analysis seems promising across several studies and may outperform STV in differentiating between IUGR and AGA fetuses. The available evidence hence supports the findings of the review in its utility.

\section{Phase plane area (PPA)}

Unlike classical methods of deriving HRV,,PPA examines the relationship of both HF and LF components of heart rate in an interactive manner [23]. Studies in the sheep model have demonstrated the corollary of high frequency components with parasympathetic activity and low frequency components with both sympathetic and parasympathetic synergism [53].

There is however, no evidence in the literature to which has demonstrated significant differences in the DI between IUGR and AGA fetuses.

\section{Differential index (DI)}

The DI is another method which is utilised to measure fetal hear rate variability. It measures the variability of the coefficients of variation of the between successive R-R intervals and its measurement is not time sensitive [54].

There is no evidence in the literature to which has demonstrated significant differences in the DI between IUGR and AGA fetuses.

\section{Cardiovascular adaptations in IUGR}

The NIEA changes encountered in IUGR fetuses are thought to occur as a result of the functional and morphological cardiac changes as well as the autonomic dysregulation which occur in these fetuses $[55,56]$. These mechanisms are further expounded in Additional file 3.

\section{Limitations of current technologies}

The findings of this review have identified several NIEA parameters which demonstrate utility in distinguishing between IUGR and AGA fetuses. Available monitoring modalities however, are limited in their ability to acquire this data.

\section{A. Cardiotocography}

CTG produces an approximation of the fetal heart rate using autocorrelation techniques which compare and average it against the previous doppler waveforms [31, 
57] . Due to this autocorrelation process however, the FHR obtained via CTG does not contain true beat to beat variability $[31,58,59]$. Furthermore, the signal obtained is of a lower resolution and is subject to various factors such as maternal expulsion efforts, uterine contractions and ventricular ectopics too [25]. This influences the readings obtained for:

\section{CTI data}

CTG is unable to capture any CTI data which precludes any temporal or morphological analysis of the FECG complex [31].

\section{STV}

Seliger et al. compared the STV obtained from cCTG against that obtained from MCG and NIFFECG and noted a loss of temporal information when the STV was calculated from cCTG based heart rate data [60]. This was further explored by Wretler et al. who noted a discrepancy between the STV calculated from the FSE when compared to cCTG [difference in STV $=0.0 \mathrm{msec}$ (R - $2.9-5.5)[61]]$.

\section{Power spectral analysis}

Power spectral analysis requires both LF and HF to allow for accurate signal processing. CTG only provides the LF components for processing thereby precluding its use [47].

The ability of the NIFECG to successfully acquire and process these signals however, is dependent on an adequate number of electrodes and a sampling rate of approximately $1000 \mathrm{~Hz}$, thereby highlighting a potential technological limitation $[62,63]$.

\section{PRSA analysis}

Both arms of the ANS operate on separate frequency domains [sympathetic component $(0.04-0.15 \mathrm{~Hz})$ and parasympathetic $(0.15-1.0 \mathrm{~Hz})]$. The $\mathrm{AC}$ and $\mathrm{DC}$ utilise the fetal R-R interval (separation between an $\mathrm{R}$ peak and the following $R$ peak) from the FECG as a key reference point for calculation. CTG however does not acquire or report any $\mathrm{R}-\mathrm{R}$ intervals which would affect the accuracy of the derivation $[25,64]$.

\section{B. Fetal scalp electrode}

The FSE generates FHR by identifying the R-R interval from the direct FECG signal. This method allows for assessment of all NIEA parameters. It is however limited by its invasive nature where it needs to be directly applied to the fetal scalp and requires the rupture of membranes. In addition, its utility antenatally is limited and it is predominantly utilised in labour. Furthermore, it has risks associated with it such as injury to the fetal scalp and the vertical transmission of infections [65].

\section{Avenues for future research direction}

This systematic review highlights that further large-scale prospective studies are required to investigate the value of NIEA techniques in differentiating between IUGR form AGA fetuses. At present, the evidence for utilising noninvasive modalities with accurate NIEA parameters, such as MCG and NIFECG, remains limited. Tables 1, 2, 3 and 4 could be utilised as a reference matrix to design these studies. The following issues should be taken into consideration when designing and executing the trials:

\section{Uniformity in definition of IUGR}

We propose that the biometric parameters of estimated fetal weight and abdominal circumference $<10 \%$ be utilised to promote uniformity across studies. Doppler indices may be utilised to further differentiating between fetuses with features of cardiovascular compensation and cerebral redistribution.

\section{Utilisation of all NIEA parameters for comparison across groups}

We suggest that the following NIEA parameters be explored in future studies: $\mathrm{P}$ wave duration, PR interval, QRS duration, QT interval, T/QRS ratio, LTV and STV. These techniques can be utilised for both the NIFECG and MCG and this will promote meta-analysis of the data. In addition, importance should be directed towards the QRS and QT duration, T/QRS ratio, STV and PRSA analysis (LTV) which show promise in their utility for IUGR evaluation. We also suggest the addition of cardiac circumference to thoracic circumference (CC/TC) ratio to explore the FECG changes related to cardiac size in an attempt to correlate this with the postulated cardiovascular changes which occur in these fetuses [27].

\section{Data analysis of NIEA parameters}

During data analysis, researchers should consider if the parameters obtained are normally distributed or would require individualisation. As demonstrated with T/QRS ratio as well as STV, the screening potential of certain parameters may be optimised through individualisation.

\section{Technological shortcomings}

We would like to highlight the technological shortcomings when utilising NIFECG between the 28th to the 32nd week of gestations given the presence of vernix caseosa in the fetus. This is known to cause signal attenuation, and this could cause false positives and false negatives to be introduced into the calculation of the NIEA parameters. This can be overcome by utilising an increased number of leads in these gestations and employing greater signal amplification and utilising more robust de-noising techniques such as adaptive maternal 
ECG cancellation as well as better noise identification through signal quality metrics [15].

\section{Timing of delivery}

An additional area of interest which is worth exploring when the NIEA parameters have been adequately defined would be the timing of delivery in IUGR fetuses on the basis of the various NIEA parameters.

\section{Limitations \\ Small sample size}

The size of the samples of the studies utilised in these studies were considerably small and this is a considerable limitation in extrapolating their findings to the general population.

\section{Quality of evidence}

Being predominantly observational in nature, the studies included in this review were at high risk of bias due to their inherent design and methodological shortcomings. This should be kept in mind when interpreting the findings.

\section{Technological consistency}

The signal acquisition and processing methods employed across studies were varied. The averaging of heart beats or width of window utilised for CTI extraction in NIEA analysis in particular could have introduce measurement bias. We propose window sizes less than $5 \mathrm{~s}$ in duration for the averaging as well given the quasi stationary nature of FHR and importance of heart rate variability in the fetus.

Even considering the limitations however, it must be highlighted that the following studies have demonstrated promise and have outlined the scientific merit in further evaluating their ability to effectively screen for IUGR.

\section{Conclusion}

NIEA analysis is in the early phase of adoption and the literature remains sparse in its utility for IUGR evaluation. The findings of this review however, suggest that there may be a role for these techniques in improving the detection of IUGR. This is hypothesised to be in relation to the cardiovascular and autonomic adaptations which occur with IUGR fetuses. In particular, the QRS and QT duration, T/QRS ratio, STV and PRSA analysis (LTV) show promise in augmenting the detection algorithms. Issues that researchers should be aware of include the definition utilised for IUGR in their studies as well as the signal acquisition and processing methods utilised. Individualisation of parameters, especially the T/QRS ratio and STV, may prove further discriminative potential.

\section{Additional files}

Additional file 1: Information relating to technologies utilised to capture NIEA parameters. (DOCX $41 \mathrm{~kb}$ )

Additional file 2: Sample of Modified Black and Down's criteria utilised for assessment of bias. (DOCX $13 \mathrm{~kb}$ )

Additional file 3: Cardiovascular adaptations in IUGR. (DOCX $40 \mathrm{~kb}$ )

\begin{abstract}
Abbreviations
AGA: Appropriate for gestation age fetuses; CTI: Cardiac time intervals; FECG: Fetal electrocardiogram; IUGR: Intra uterine growth restriction; LTV: Long term variability; MCG: Fetal magnetocardiogram; MECG: Maternal ECG; NIEA: Non-invasive electrophysiological assessment; NIFECG: Noninvasive fetal electrocardiogram; SGA: Small for gestational age fetus; SNR: Signal-to-noise ratio; STV: Short term variability
\end{abstract}

\section{Acknowledgements}

We would like to acknowledge the contributions of Sathya Krishnan in the aid extended in several iterations of the revision of the article.

Ethics approval to consent and participate

Not applicable.

\section{Authors' contributions}

VS, AN, RW, JAS were involved in the search, citation review and selection process for the article. The assessment of bias was carried out by VS and RW. All authors (VS, AN, RW, JAS, FdsC, EMW) were equally involved in the conception, editing, and review process of the article. All authors have read and approve the final version of the manuscript.

\section{Funding}

No funding was provided for the following study.

Availability of data and materials

All data generated or analysed during the study is included in this published article.

Consent for publication

Not applicable.

\section{Competing interests}

VS owns shares and works as a consultant for Biorithm Pte Ltd. AN, JAS and RW are employees of Biorithm Pte Ltd. EMW, and FDC have no competing interests.

\section{Author details}

${ }^{1}$ Department of Obstetrics and Gynaecology, Monash University, 252 Clayton Road, Clayton, Victoria 3168, Australia. ${ }^{2}$ Biorithm Pte Ltd, 81 Ayer Rajah Crescent 03-53, Singapore 139967, Singapore. ${ }^{3}$ Department of Gynecology and Obstetrics, Ribeirão Preto Medical School, Ribeirão Preto, São Paulo, Brazil.

Received: 18 July 2018 Accepted: 12 June 2019

Published online: 05 July 2019

\section{References}

1. de Onis M, Blössner M, Villar J. Levels and patterns of intrauterine growth retardation in developing countries. Eur J Clin Nutr. 1998:52(Suppl 1):S5-15.

2. Unterscheider J, O'Donoghue K, Malone FD. Guidelines on fetal growth restriction: a comparison of recent National Publications. Amer J Perinatol. 2015;32(04):307-16.

3. Unterscheider J, Daly S, Geary MP, Kennelly MM, McAuliffe FM, O'Donoghue K, Hunter A, Morrison JJ, Burke G, Dicker P, et al. Optimizing the definition of intrauterine growth restriction: the multicenter prospective PORTO study. Am J Obstet Gynecol. 2013;208(4):290.e291-6.

4. Gordijn SJ, Beune IM, Thilaganathan B, Papageorghiou A, Baschat AA, Baker PN, Silver RM, Wynia K, Ganzevoort W. Consensus definition of fetal growth restriction: a Delphi procedure. Ultrasound Obstet Gynecol. 2016;48(3):333-9.

5. Suhag A, Berghella V. Intrauterine growth restriction (IUGR): etiology and diagnosis. Current Obstet Gynecol Rep. 2013;2(2):102-11. 
6. Bukowski R, Burgett AD, Gei A, Saade GR, Hankins GD. Impairment of fetal growth potential and neonatal encephalopathy. Am J Obstet Gynecol. 2003; 188(4):1011-5

7. Unterscheider J, O'Donoghue K, Daly S, Geary MP, Kennelly MM, McAuliffe FM, Hunter A, Morrison JJ, Burke G, Dicker P, et al. Fetal growth restriction and the risk of perinatal mortality-case studies from the multicentre PORTO study. BMC Pregnancy Childbirth. 2014;14:63.

8. Chauhan SP, Rouse DJ, Ananth CV, Magann EF, Chang E, Dahlke JD, Abuhamad AZ. Screening for intrauterine growth restriction in uncomplicated pregnancies: time for action. Am J Perinatol. 2013;30(1):33-9.

9. Levine TA, Grunau RE, McAuliffe FM, Pinnamaneni R, Foran A, Alderdice FA. Early childhood neurodevelopment after intrauterine growth restriction: a systematic review. Pediatrics. 2015;135(1):126-41.

10. Murray E, Fernandes M, Fazel M, Kennedy SH, Villar J, Stein A. Differential effect of intrauterine growth restriction on childhood neurodevelopment: a systematic review. BJOG. 2015;122(8):1062-72.

11. Sharma D, Farahbakhsh N, Shastri S, Sharma P. Intrauterine growth restriction - part 2. J Matern Fetal Neonatal Med. 2016;29(24):4037-48.

12. Figueras F, Gratacos E. An integrated approach to fetal growth restriction. Best Pract Res Clin Obstet Gynaecol. 2017;38:48-58.

13. Lewis MJ. Review of electromagnetic source investigations of the fetal heart. Med Eng Phys. 2003;25(10):801-10.

14. Aubut JA, Marshall S, Bayley M, Teasell RW. A comparison of the PEDro and downs and black quality assessment tools using the acquired brain injury intervention literature. NeuroRehabilitation. 2013;32(1):95-102.

15. Anastasiadis PG, Kotini A, Anninos P, Adamopoulos A, Sigalas J, Koutlaki N. Chaotic and periodic analysis of fetal magnetocardiogram recordings in growth restriction. Prenat Diagn. 2003;23(5):405-9.

16. Brambati $B$, Bonsignore $L$. Intraventricular conduction time in fetuses born with growth retardation. Br J Obstet Gynaecol. 1982; 89(11):900-3

17. Fuchs $T$. Values of $T / Q R S$ ratio in pregnancies complicated by intrauterine growth restriction. J Perinat Med. 2016;44(7):751-7.

18. Fuchs $T$, Grobelak K, Pomorski M, Zimmer M. Fetal heart rate monitoring using maternal abdominal surface electrodes in third trimester: can we obtain additional information other than CTG trace? Adv Clin Exp Med. 2016;25(2):309-16.

19. Graatsma EM, Mulder EJH, Vasak B, Lobmaier SM, Pildner von Steinburg S, Schneider KTM, Schmidt G, Visser GHA. Average acceleration and deceleration capacity of fetal heart rate in normal pregnancy and in pregnancies complicated by fetal growth restriction. J Matern Fetal Neonatal Med. 2012;25(12):2517-22.

20. Grimm B, Kaehler C, Schleussner E, Schneider U, Haueisen J, Seewald HJ. Influence of intrauterine growth restriction on cardiac time intervals evaluated by fetal magnetocardiography. Early Hum Dev. 2003;74(1):1-11.

21. Kariniemi V, Ammala P. Short-term variability of fetal heart rate during pregnancies with normal and insufficient placental function. Am J Obstet Gynecol. 1981;139(1):33-7.

22. Pardi G, Marconi A, Ferrazzi E. The intraventricular conduction time of fetal heart in pregnancies with suspected fetal growth retardation. $\mathrm{Br} J$ Obstet Gynaecol. 1986;93(3):250-4.

23. Sriram B, Mencer MA, McKelvey S, Siegel ER, Vairavan S, Wilson JD, Preissl H, Eswaran H, Govindan RB. Differences in the sleep states of IUGR and low-risk fetuses: an MCG study. Early Hum Dev. 2013; 89(10):815-9.

24. Stampalija T, Casati D, Monasta L, Sassi R, Rivolta MW, Muggiasca ML, Bauer A, Ferrazzi E. Brain sparing effect in growth-restricted fetuses is associated with decreased cardiac acceleration and deceleration capacities: a casecontrol study. BJOG. 2016;123(12):1947-54

25. Stampalija T, Casati D, Montico M, Sassi R, Rivolta MW, Maggi V, Bauer A, Ferrazzi E. Parameters influence on acceleration and deceleration capacity based on trans-abdominal ECG in early fetal growth restriction at different gestational age epochs. Eur J Obstet Gynecol Reprod Biol. 2015;188:104-12.

26. van Leeuwen P, Schiermeier S, Lange S, Klein A, Geue D, Hatzmann W, Gronemeyer DH. Gender-related changes in magnetocardiographically determined fetal cardiac time intervals in intrauterine growth retardation. Pediatr Res. 2006:59(6):820-4.

27. Velayo $\mathrm{CL}$, Funamoto K, Silao JNI, Kimura Y, Nicolaides K. Evaluation of abdominal fetal electrocardiography in early intrauterine growth restriction. Front Physiol. 2017;8:437.

28. Schneider U, Fiedler A, Liehr M, Kahler C, Schleussner E. Fetal heart rate variability in growth restricted fetuses. Biomed Tech (Berl). 2006;51(4):248-50.
29. Bolin EH, Siegel ER, Eswaran H, Lowery CL, Zakaria D, Best TH. Cardiac time intervals derived by magnetocardiography in fetuses exposed to pregnancy hypertension syndromes. J Perinatol. 2016;36(8):643-8.

30. Fukushima A, Nakai K, Kanasugi T, Terata M, Sugiyama T. Assessment of fetal autonomic nervous system activity by fetal magnetocardiography: comparison of normal pregnancy and intrauterine growth restriction. J Pregnancy. 2011;2011:218162.

31. Smith V, Arunthavanathan S, Nair A, Ansermet D, da Silva Costa F, Wallace EM. A systematic review of cardiac time intervals utilising non-invasive fetal electrocardiogram in normal fetuses. BMC Pregnancy Childbirth. 2018;18(1):370

32. Brambati B, Pardi G. The intraventricular conduction time of fetal heart in pregnancies complicated by rhesus haemolytic disease. Br J Obstet Gynaecol. 1981;88(12):1233-40.

33. Velayo C, Calvo JR, Sato N, Kimura Y, Yaegashi N, Nicolaides K. Evaluation of cardiac performance by abdominal fetal ECG in twin-to-twin transfusion syndrome. Prenat Diagn. 2012;32(11):1059-65.

34. Greene KR, Dawes GS, Lilja H, Rosen KG. Changes in the ST waveform of the fetal lamb electrocardiogram with hypoxemia. Am J Obstet Gynecol. 1982;144(8):950-8.

35. Rosen KG. Alterations in the fetal electrocardiogram as a sign of fetal asphyxia--experimental data with a clinical implementation. J Perinat Med. 1986;14(6):355-63.

36. Widmark C, Jansson T, Lindecrantz K, Rosen KG. ECG wave form, short term heart rate variability and plasma catecholamine concentrations in intrauterine growth-retarded Guinea-pig fetuses. J Dev Physiol. 1990;13(5):289-93.

37. Watanabe T, Okamura K, Tanigawara S, Shintaku Y, Akagi K, Endo H, Yajima A. Change in electrocardiogram T-wave amplitude during umbilical cord compression is predictive of fetal condition in sheep. Am J Obstet Gynecol. 1992;166(1 Pt 1):246-55.

38. van Wijngaarden WJ, Strachan BK, Sahota DS, James DK. Improving intrapartum surveillance: an individualised T/QRS ratio? Eur J Obstet Gynecol Reprod Biol. 2000;88(1):43-8.

39. Street P, Dawes GS, Moulden M, Redman CW. Short-term variation in abnormal antenatal fetal heart rate records. Am J Obstet Gynecol. 1991;165(3):515-23

40. Dawes GS, Moulden M, Redman CW. Short-term fetal heart rate variation, decelerations, and umbilical flow velocity waveforms before labor. Obstet Gynecol. 1992;80(4):673-8.

41. Minato T, Ito T, Kasahara Y, Ooshio S, Fushima T, Sekimoto A, Takahashi N, Yaegashi N, Kimura Y. Relationship between short term variability (STV) and onset of cerebral hemorrhage at ischemia-reperfusion load in fetal growth restricted (FGR) mice. Front Physiol. 2018;9:478.

42. Signorini MG, Fanelli A, Magenes G. Monitoring fetal heart rate during pregnancy: contributions from advanced signal processing and wearable technology. Computat Math Methods Med. 2014;2014:707581.

43. Ayres-de-Campos D, Spong CY, Chandraharan E. FIGO consensus guidelines on intrapartum fetal monitoring: Cardiotocography. Int J Gynecol Obstet. 2015;131(1):13-24.

44. Stroux L, Redman CW, Georgieva A, Payne SJ, Clifford GD. Doppler-based fetal heart rate analysis markers for the detection of early intrauterine growth restriction. Acta Obstet Gynecol Scand. 2017;96(11):1322-9.

45. Mortara A, La Rovere MT, Signorini MG, Pantaleo P, Pinna G, Martinelli L, Ceconi C, Cerutti S, Tavazzi L. Can power spectral analysis of heart rate variability identify a high risk subgroup of congestive heart failure patients with excessive sympathetic activation? A pilot study before and after heart transplantation. Br Heart J. 1994;71(5):422-30.

46. Muiesan ML, Rizzoni D, Zulli R, Castellano M, Bettoni G, Porteri E, AgabitiRosei E. Power spectral analysis of the heart rate in hypertensive patients with and without left ventricular hypertrophy: the effect of a left ventricular mass reduction. J Hypertens. 1998;16(11):1641-50.

47. Ohta T, Okamura K, Kimura Y, Suzuki T, Watanabe T, Yasui T, Yaegashi $N$, Yajima A. Alteration in the low-frequency domain in power spectral Analysisof fetal heart beat fluctuations. Fetal Diagn Ther. 1999;14(2):92-7.

48. Signorini MG, Magenes G, Cerutti S, Arduini D. Linear and nonlinear parameters for the analysisof fetal heart rate signal from cardiotocographic recordings. IEEE Trans Biomed Eng. 2003;50(3):365-74.

49. Bauer A, Kantelhardt JW, Bunde A, Barthel P, Schneider R, Malik M, Schmidt G. Phase-rectified signal averaging detects quasi-periodicities in nonstationary data. Physica A. 2006;364:423-34.

50. Bauer A, Kantelhardt JW, Barthel P, Schneider R, Mäkikallio T, UIm K, Hnatkova K, Schömig A, Huikuri H, Bunde A, et al. Deceleration capacity of 
heart rate as a predictor of mortality after myocardial infarction: cohort study. Lancet. 2006:367(9523):1674-81.

51. Huhn EA, Lobmaier S, Fischer T, Schneider R, Bauer A, Schneider KT, Schmidt G. New computerized fetal heart rate analysis for surveillance of intrauterine growth restriction. Prenat Diagn. 2011;31(5):509-14.

52. Lobmaier SM, Huhn EA, Pildner von Steinburg S, Müller A, Schuster T, Ortiz JU, Schmidt G, Schneider KT. Phase-rectified signal averaging as a new method for surveillance of growth restricted fetuses. J Matern Fetal Neonatal Med. 2012;25(12):2523-8.

53. van Laar JO, Peters CH, Vullings R, Houterman S, Oei SG. Power spectrum analysis of fetal heart rate variability at near term and post term gestation during active sleep and quiet sleep. Early Hum Dev. 2009;85(12):795-8.

54. Yeh HS-Y, Forsythe HA, Hon HE. Quantification of fetal heart beat-to-beat interval differences. Obstet Gynecol. 1973;41(3):355-63.

55. Baschat AA. Planning management and delivery of the growth-restricted fetus. Best Pract Res Clin Obstet Gynaecol. 2018;49:53-65.

56. Khalil A, Thilaganathan B. Role of uteroplacental and fetal Doppler in identifying fetal growth restriction at term. Best Pract Res Clin Obstet Gynaecol. 2017;38:38-47.

57. Peters $\mathrm{CH}$, ten Broeke ED, Andriessen P, Vermeulen B, Berendsen RC, Wijn PF, Oei SG. Beat-to-beat detection of fetal heart rate: Doppler ultrasound cardiotocography compared to direct ECG cardiotocography in time and frequency domain. Physiol Meas. 2004;25(2):585-93.

58. Behar J, Andreotti F, Zaunseder S, Oster J, Clifford GD. A practical guide to non-invasive foetal electrocardiogram extraction and analysis. Physiol Meas. 2016;37(5):R1-r35.

59. Clifford GD, Silva I, Behar J, Moody GB. Non-invasive fetal ECG analysis. Physiol Meas. 2014;35(8):1521-36.

60. Seliger G, Stenzel A, Kowalski EM, Hoyer D, Nowack S, Seeger S, Schneider $U$. Evaluation of standardized, computerized Dawes/Redman heart-rate analysis based on different recording methods and in relation to fetal beatto-beat heart rate variability. J Perinat Med. 2016;44(7):785-92.

61. Wretler S, Holzmann M, Graner S, Lindqvist P, Falck S, Nordström L. Fetal heart rate monitoring of short term variation (STV): a methodological observational study. BMC Pregnancy Childbirth. 2016;16(1):55.

62. Stampalija T, Eleuteri A, Signaroldi M, Mastroianni C, Fisher A, Ferrazzi E, Alfirevic Z. 662: power spectral analysis of trans-abdominal fetal ECG at the beginning of labour as a predictor of adverse pregnancy outcome. Am J Obstet Gynecol. 2011;204(1):S261.

63. Yeh H-M, Chang Y-C, Lin C, Yeh C-H, Lee C-N, Shyu M-K, Hung M-H, Hsiao $\mathrm{P}-\mathrm{N}$, Wang $\mathrm{Y}-\mathrm{H}$, Tseng $\mathrm{Y}-\mathrm{H}$, et al. A new method to derive fetal heart rate from maternal abdominal electrocardiogram: monitoring fetal heart rate during cesarean section. PLoS One. 2015;10(2):e0117509.

64. Akselrod S, Gordon D, Ubel FA, Shannon DC, Berger AC, Cohen RJ. Power spectrum analysis of heart rate fluctuation: a quantitative probe of beat-tobeat cardiovascular control. Science (New York, NY). 1981;213(4504):220-2.

65. Agostinelli A, Grillo M, Biagini A, Giuliani C, Burattini L, Fioretti S, Di Nardo F, Giannubilo SR, Ciavattini A, Burattini L. Noninvasive fetal electrocardiography: an overview of the signal electrophysiological meaning, recording procedures, and processing techniques. Ann Noninvasive Electrocardiol. 2015;20(4):303-13.

66. Pieri JF, Crowe JA, Hayes-Gill BR, et al. Compact long-term recorder for the transabdominal foetal and maternal electrocardiogram. Med Biol Eng Comput. 2001;39(1):118-25.

67. Schneider U, Schleussner E, Haueisen J, et al. Signal Analysis of Auditory Evoked Cortical Fields in Fetal Magnetoencephalography. Brain Topogr. 2001;14(1):69-80. https://doi.org/10.1023/a:1012519923583.

\section{Publisher's Note}

Springer Nature remains neutral with regard to jurisdictional claims in published maps and institutional affiliations.

Ready to submit your research? Choose BMC and benefit from:

- fast, convenient online submission

- thorough peer review by experienced researchers in your field

- rapid publication on acceptance

- support for research data, including large and complex data types

- gold Open Access which fosters wider collaboration and increased citations

- maximum visibility for your research: over $100 \mathrm{M}$ website views per year

At BMC, research is always in progress.

Learn more biomedcentral.com/submissions 